\title{
NO BUYERS
}

\section{A STREET SCENE}

A LOAD of brushes and baskets and cradles and chairs

Labours along the street in the rain:

With it a man, a woman, a pony with whiteybrown hairs. -

The man foots in front of the horse with a shambling sway

At a slower tread than a funeral train,

While to a dirge-like tune he chants his wares,

Swinging a Turk's-head brush (in a drum-major's way

When the bandsmen march and play).

A yard from the back of the man is the whiteybrown pony's nose:

He mirrors his master in every item of pace and pose:

He stops when the man stops, without being told, And seems to be eased by a pause; too plainly he's old, Indeed, not strength enough shows

To steer the disjointed waggon straight, Which wriggles left and right in a rambling line,

Deflected thus by its own warp and weight,

And pushing the pony with it in each incline.

The woman walks on the pavement verge,

Parallel to the man:

She wears an apron white and wide in span, And carries a like Turk's-head, but more in nursing-wise:

Now and then she joins in his dirge,

But as if her thoughts were on distant things.

The rain clams her apron till it clings. -

So, step by step, they move with their merchandize,

And nobody buys. 